Article

\title{
Drumming the Barrels of Hope? Bioeconomy Narratives in the Media
}

\author{
Juha Peltomaa \\ Finnish Environment Institute, 00251 Helsinki, Finland; juha.peltomaa@ymparisto.fi \\ Received: 11 October 2018; Accepted: 15 November 2018; Published: 19 November 2018
}

\begin{abstract}
Bioeconomy as one mode of the transition towards a more sustainable mode of production and consumption has been addressed in several policy fields. Bioeconomy has raised hope not only in the quest for a more sustainable future, but also offers new possibilities, especially in countries with vast natural resources. By using the Narrative Policy Framework, I assess the kinds of bioeconomy narratives promoted by the media and the future they suggest, for the case of Finland. Flexible concepts such as bioeconomy can be harnessed to promote different, and even contrasting, objectives. Besides growth-oriented promises, bioeconomy seems to simultaneously raise controversial questions related to techno-social path dependencies and the sustainability of natural resource use. The narratives seem also to lack roles for certain actor groups, such as citizens, which might challenge the legitimacy and, thus, the future of bioeconomy. The role of civil society should also be better addressed by scholars in the field, as it plays an important role in the sustainability of bioeconomy.
\end{abstract}

Keywords: policy narratives; narrative policy framework; media; natural resource governance

\section{Introduction}

Various supranational and national policies are increasingly stressing the importance of establishing paths towards sustainable modes of production and consumption. As part of the circular economy approach, bioeconomy has been recognized as one way of meeting the rising sustainability challenges. In short, bioeconomy means an economy that is based on the sustainable use of renewable resources to produce food, energy, products, and services [1]. However, the use and understanding of the concept in policy, academia, and practice is nothing short of ambiguous, ranging from, for example, the use of advanced molecular level biotechnology to replacing fossil fuels with burning forest-based materials [2,3].

Bioeconomy has gained prominence especially in countries with vast natural resources, such as the Nordic countries [3-6]. In Finland, more than half of the current bioeconomy is based on forests [7]. Therefore, bioeconomy, as such, is nothing particularly new. The Finnish national economy has been largely based on the use of forests for centuries [8]. Bioeconomy also has extensive societal aims as there are several large-scale biorefineries either planned or in the making, and bioeconomy is also one of the five "spearhead initiatives" of the Finnish government that are supported by the 2015 national bioeconomy strategy.

Bioeconomy, as a rapidly emerging policy sphere, has not gone unnoticed in the scientific literature either. Analysis on bioeconomy policies concerning the different levels of governance and varying contexts in the 2010's was plentiful [3,6,9,10]. Besides policy document analysis [5,11,12], literature reviews [2,13], stakeholder interviews, and surveys $[4,14]$ have been recurrent data sources.

Despite the momentum that bioeconomy has gained, critical voices have also been raised. The application of bioeconomy as a political buzzword has been criticized for offering a top-down 
technical solution [15] and being exclusive [16]. The ecological and social sustainability of bioeconomy has also been questioned [15,17]. Despite the critique, bioeconomy is not just a catchword but a concept with a genuine quest for a more sustainable future. It is a concept made of words, and words change things; they possess power [14]. Some concepts have the power to change real-life processes and eventually lead to a paradigm shift [18]. Furthermore, due to the ambiguousness of the concept, bioeconomy possess interpretative flexibility in ways that can be used for the specific needs of diverse actors and objectives [19]. The use of the concept thus makes a difference in how it affects practices that shape the future.

The research focus thus far on policy documents and expert insights offers important information on how bioeconomy is comprehended in different realms. However, one important domain that is crucial when discussing bioeconomy policies has received less attention: the media. Narratives in the media reflect public opinion but are also shaped by it. These narratives function similarly regarding policy processes and can also support or question the legitimacy of policy issues. The media offers a platform for political actors to present their views but can also represent certain viewpoints or interests more directly $[20,21]$. These weightings can be unintentional but can also reflect the ways in which a medium wants to represent certain societal groups, political interests, parties, or regional stances. Therefore, it is especially important to recognize the kinds of narratives to which ambiguous concepts such as bioeconomy are attached.

To assess these narratives and contribute to the recent discussion of the makings of bioeconomy in this journal [3-5,10,12], I analyze the contents of four major Finnish newspapers from 2014-2015 during the formation of the government of 2015 and compare this with the contents from five years earlier in 2009-2010. By using the narrative policy framework (NPF) complemented with word frequency analysis, the accuracy and rigorousness of the previously recognized bioeconomy narratives can also be enhanced. By doing this, it is also possible to scrutinize how these previously recognized narratives, which were mostly based on policy documents and expert insights, relate to the wider societal discussions in the media and fill this important deficit. For these tasks, I propose the following research questions:

1. What kinds of bioeconomy narratives do the media use?

2. Who are the actors in these narratives?

3. What kinds of futures do the narratives create?

In the following text, I first introduce my approach to bioeconomy as a policy narrative and the $\mathrm{NPF}$, data, and methodology used to provide answers to the research questions. In Section 3, I present the word frequency indications, elaborate the full policy narratives, and show how the narratives were distributed among the newspapers. In the latter part of the article, I discuss the roles of the actors in the narratives and assess how the backgrounds of the journals affect how the different newspapers use the narratives. Finally, I reflect on the practical implications that the narratives might have on the related policies and other societal developments in the future.

\subsection{Bioeconomy as a Policy Narrative}

Methodologically, the research on bioeconomy has often applied narrative approaches, especially within the European policy context [10-12,22]. Hansen and Bjørkhaug [4], for example, traced the kinds of expectations that bioeconomy has created in the Norwegian policy environment among the different actors, indicating that achieving anything other than incremental changes has proved to be challenging. Similarly, Bauer [14] recognized the ambiguousness of bioeconomy, a factor that allows actors with vested but sometimes conflicting interests to push their agendas, which are often based on business-as-usual. In steering these processes, policymakers should be careful in recognizing how these interests could be consolidated.

Bugge et al. traced three visions of bioeconomy in the research literature [2]. Following these, Hausknost et al. [10], in line with Staffas et al. [23], distinguished three narratives in the documents that 
steer national and supranational bioeconomy policymaking, and in the preparation of the Norwegian national bioeconomy strategy, e.g., Scordato et al. [3]. These three approaches to the use of bioeconomy as a biotechnology, bioresource and agro-ecology have thus been noted to appear in both the research and policy domains.

The biotechnology-centered narrative sees bioeconomy as being dependent on the knowledge and technology in the related fields and has a founding especially in the knowledge-based-bioeconomy approach that was promoted by the EU and originated from the 2000 Lisbon Agenda. This approach is also eminent in the related OECD policies that emphasize technological aspects such as the significance of biotechnological development [24]. The resource-centered narrative looks at bioeconomy more from the resource use perspective and has arisen especially along the 2010's regarding tackling climate change and EU bioenergy policies [25-27]. In particular, the resource-centered narrative seems to have a foothold in the policies of resource abundant societies, such as the Nordic countries. These countries have a long history of existing industries that are dependent on forest resources which influence the related policies [6]. Along the two dominant narratives, the agroecological bioeconomy narrative is particularly supported by environmental non-governmental organizations (NGOs) and certain academic research. It approaches bioeconomy as being integrated with the wider issues of societal sustainability.

These three narratives can be located on a conceptual matrix of techno-political option space with two dimensions (Figure 1) [10]. The $x$-axis forms a political-economic dimension between sufficiency and capitalist growth, and the $y$-axis forms a technological dimension between industrial (bio)technology and agro-ecology.

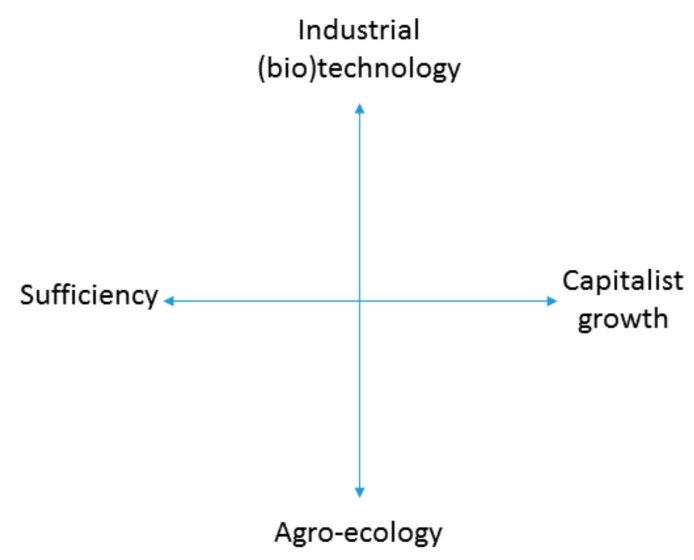

Figure 1. Techno-political option space of bioeconomy (adapted from Hausknost et al. [10]).

According to Hausknost et al. [10], both the biotechnology and resource-centered narratives tend to lean towards the growth paradigm on the $x$-axis. On the $y$-axis, the biotechnology narrative leans understandably towards industrial (bio)technology, but the resource-centered narrative is also geared towards technology rather than agroecological processes. This makes industrial technologies within the resource-centered narrative instrumental elements in using the resources. The agroecological narrative is a balance between sufficiency and growth on the political-economic $x$-axis and leans towards the more holistic agro-ecology in the technological $y$-axis. However, despite the lesser emphasis on capitalist growth in the agroecological narrative, Hausknost et al. [10] claim that, especially in the policy domain, the narratives rarely really question the growth paradigm. The support for more sufficiency-based bioeconomy often stems from NGOs and, to some degree, the research community.

\subsection{Analyzing Policy Narratives in the Media}

Policies can be understood to be reflected in narratives, and policy processes can be analyzed as struggles over narratives $[28,29]$. The NPF is a way to structure these narratives and analyze the roles assigned to the different actors in policy processes. As is understood here, bioeconomy is a policy 
process with partially conflicting visions and standing points. By stressing the role of narratives as essential factors and influencers in policy processes, narratives can be understood as affecting both policy design and implementation [30,31].

The NPF is a framework developed during the 2010's aiming to enhance the coherence of narrative analysis. However, it is sometimes criticized for being ambiguous or subjective [28,29]. With emphasis on the rigorousness of the methodologies used, the NPF stresses the power of narratives in policy processes and aims to complement the more established policy change literature, such as the Advocacy Coalition Framework (ACF) [32].

The NPF analysis is based on indications of certain recurrent elements that appear in varying combinations [30]. These elements consist of a setting, meaning the context for the narrative and characters, who can be either heroes who can solve the policy problem at hand, villains responsible for the problem, or victims suffering from the problem. A plot connects the characters to the policy setting and to each other, and a moral of the story or policy solution provides solutions to the particular problem or issue. One key factor in the NPF analysis is the contextualization of the elements in the wider institutional landscape that conditions the narrative. $[28,29]$. In the case of bioeconomy in Finland, one key aspect of this landscape is the significance of the forest industry and the power positions of the related advocacy groups.

The NPF works as a methodological tool but has also characteristics of a theory linking the different elements of the framework together and offering leverage to aid in the understanding of policy processes. To complement the use of the NPF and contribute to the quest for rigorousness, I also used a quantitative word frequency analysis [33] to make a preliminary mapping of the actors, substance areas, and visions in the data to better elaborate the NPF elements and thus the full policy narratives. In a broader sense, combining the rigorousness of a word frequency analysis with the premises of the NPF in locating the narratives in a wider policy context also offers the tools to understand how the media affects policy design and implementation.

\section{Data and Methods}

In this article, the three previously recognized narratives-biotechnology, bioresources, and agro-ecology — are taken as a starting point to analyze what they consist of in the media discussion. This discussion potentially differs from previously studied policy agendas or professional insights in that media allows for a more diverse set of stances to be voiced.

The data consists of bioeconomy-related discussions in four major Finnish newspapers, Helsingin Sanomat, Maaseudun Tulevaisuus, Keskisuomalainen and Kauppalehti, from January to December in 2010-2011 and 2015-2016 (Table 1). Each newspaper has an online archive, and I searched for articles mentioning bioeconomy in the different inflected forms (biotalou*). I collected a total of 1264 articles, 106 articles in 2010-2011 and 1158 articles in 2015-2016. The articles were divided based on the content of the papers' editorial lines, such as news stories, editorials, and content not produced by the paper personnel, such as readers' opinion pieces.

Table 1. The analyzed articles mentioning bioeconomy (biotalou*) in the four newspapers in 2010-2011 and 2015-2016.

\begin{tabular}{|c|c|c|c|c|c|c|}
\hline \multirow{3}{*}{ Newspaper } & \multicolumn{6}{|c|}{ Year } \\
\hline & \multicolumn{3}{|c|}{ 2010-2011 } & \multicolumn{3}{|c|}{ 2015-2016 } \\
\hline & $\begin{array}{c}\text { News Story, } \\
\text { Editorial, Column }\end{array}$ & Opinion & Total & $\begin{array}{c}\text { News Story, } \\
\text { Editorial, Column }\end{array}$ & Opinion & Total \\
\hline Helsingin Sanomat & 15 & 5 & 20 & 172 & 46 & 218 \\
\hline $\begin{array}{l}\text { Maaseudun } \\
\text { Tulevaisuus }\end{array}$ & 69 & - & 69 & 557 & 68 & 625 \\
\hline Keskisuomalainen & 7 & 2 & 9 & 209 & 50 & 259 \\
\hline Kauppalehti & 8 & 0 & 8 & 40 & 16 & 56 \\
\hline Total & & & 106 & & & 1158 \\
\hline
\end{tabular}


The newspapers were selected based on circulation and regional and business representation. Despite being general newspapers, the studied newspapers can be characterized to represent slightly varying viewpoints towards bioeconomy. Helsingin Sanomat is the leading daily newspaper in Finland with 679,000 readers [34] making it the most read daily newspaper. Maaseudun Tulevaisuus is the second most read newspaper with 306,000 readers [35]. Maaseudun Tulevaisuus has a special focus on rural issues; the publisher is owned by the Finnish Central Union of Agricultural Producers and Forest Owners and three issues are published per week. Keskisuomalainen is the fifth most circulated daily newspaper in Finland with 124,000 readers [36]. The daily Keskisuomalainen is a regional newspaper from Central Finland and one of the large biorefineries is also located in this region. The paper has roots in the Center coalition but has been politically nonaligned since 1986. The fourth newspaper is Kauppalehti, the leading business media in Finland. It has 134,000 readers and publishes five issues per week [37].

All articles were analyzed in terms of their word frequencies to get an overview and to determine the NPF elements of their contexts, settings, and characters. The word frequency analysis [33] was run with nVivo software. The 2010-2011 data set consisted of 32,336 words, and the 2015-2016 data set had 425,880 words. The results were cleaned to eliminate "empty" words, such as conjunctions, and the different inflections and synonyms were combined. To recognize the NPF elements, the frequency analysis results were grouped into different categories which reflected the NPF classifications. The categories reflected the NPF categories of context (location, country, municipality, etc.), the substance or topic area as the setting (e.g., field of business, production, or livelihood) and actors as the characters (e.g., party, person, company, institution).

After this, the articles were read, and the NPF elements and the narratives they produced were assessed, as the mechanical word frequency analysis does not answer what kinds of connotations and meanings the words carry. During the reading, I tested whether the three previously indicated narratives, biotechnology-centered bioeconomy (1), resource-centered bioeconomy (2), and agroecological bioeconomy (3), appeared in the data sets. This was done by assessing whether the core perspectives and basis of the three narratives (see Section 1.1) appeared in the analyzed data sets. The three narratives were clearly present in a similar form as had been recognized before. I then continued to combine the word frequency results with the NPF elements to elaborate the three full policy narratives in accordance with the NPF classifications. After explicating the full narratives, the articles representing these three narratives were indicated from the data (Appendix A).

During the elaboration of the narratives, several articles that did not explicitly fit into the three preselected narratives were indicated separately. From these, a set of NPF elements not fitting to the three narratives was recognized. These elements were then clustered and recognized to represent two additional narratives: bioeconomy as skillfulness (4), and climate change-centered bioeconomy (5). In addition, there were also articles that did not represent any narratives. These were mostly short report-style articles that briefly mentioned bioeconomy without any meaning or context attached to them. These were marked as representing none of the five narratives and were excluded from the full policy narrative material. Finally, the content of the narratives was analyzed against the two-dimensional matrix developed by Hausknost et al. [10].

\section{Results}

\subsection{Word Frequency Analysis}

Forests and wood in general played dominant roles in the articles in both time periods. This was also the case when looking at the most frequent topic area words. The word frequency analysis showed a strong emphasis on the use of forests, and the actors were mostly forest owners, the forest industry and the actors and institutions representing these (Table 2).

In the 2015-2016 data, state actors appeared more often than in 2010-2011. The bioeconomy initiatives by the 2015 elected government reflect this. The Center Party, which has been a vocal 
advocate of bioeconomy, along with their Prime Minister, Juha Sipilä (706), got twice as many hits (846) compared to the next party, the National Coalition (383). The third party involved in these discussions was the Greens (250), who were not part of the 2015 government.

As an example, the seven most recurrent words in 2010-2011 and 2015-2016 regarding the context, setting, and characters are represented in Table 2.

Table 2. The most recurring contexts, settings, and characters of the bioeconomy articles in the analyzed newspapers in 2010-2011 and 2015-2016.

\begin{tabular}{|c|c|c|c|c|c|}
\hline \multicolumn{3}{|c|}{ 2010-2011 } & \multicolumn{3}{|c|}{ 2015-2016 } \\
\hline Context & Setting & Characters & Context & Setting & Characters \\
\hline Finland & Forest & Forest owners & Finland & Forest & Center Party \\
\hline Countryside & Wood & Government & Central Finland & Wood & Company \\
\hline Country & Energy & Ministry & Countryside & Energy & Sipilä (PM) \\
\hline World & Forest industry & Metsäliitto ** & Äänekoski & Forest industry & MTK * \\
\hline Europe & Food & $\begin{array}{l}\text { Ministry of agric. } \\
\text { and forestry }\end{array}$ & Country & Agriculture & State \\
\hline Russia & Forestry & MTK* & Europe & Education & National Coalition \\
\hline Helsinki & Bioenergy & UPM ** & World & Forestry & Party \\
\hline
\end{tabular}

* Finnish Central Union of Agricultural Producers and Forest Owners, ${ }^{* *}$ Forest companies.

\subsection{Policy Narratives}

The elements of the five full policy narratives are presented in Table 3, followed by an elaboration on what the key claims of the narratives are.

Table 3. The full policy narratives in the analyzed bioeconomy articles in the newspapers and the narrative policy framework (NPF) elements that the narratives consist of.

\begin{tabular}{|c|c|c|c|c|}
\hline Narrative & Setting & Characters & Plot & Policy Solution \\
\hline $\begin{array}{c}1 \\
\begin{array}{l}\text { Biotechnology-centered } \\
\text { bioeconomy }\end{array}\end{array}$ & $\begin{array}{l}\text { Bioeconomy is about } \\
\text { innovation and new } \\
\text { technologies using } \\
\text { natural processes } \\
\text { or materials }\end{array}$ & $\begin{array}{l}\text { Hero: scientists, } \\
\text { innovators } \\
\text { Villain: short-sighted } \\
\text { policymakers } \\
\text { Victim: } \\
\text { economy, nature }\end{array}$ & $\begin{array}{l}\text { Investing in technological } \\
\text { innovations brings novel } \\
\text { solutions to tackle problems } \\
\text { such as pollution or health } \\
\text { while making Finland the } \\
\text { leader in bioeconomy. }\end{array}$ & $\begin{array}{l}\text { The societal focus } \\
\text { should be on } \\
\text { innovation policies and } \\
\text { support mechanisms } \\
\text { for the promises of } \\
\text { bioeconomy to realize }\end{array}$ \\
\hline $\begin{array}{c}2 \\
\begin{array}{l}\text { Resource-centered } \\
\text { bioeconomy }\end{array}\end{array}$ & $\begin{array}{l}\text { Bioeconomy is about } \\
\text { using bio-based } \\
\text { resources to replace } \\
\text { existing materials and } \\
\text { sources of energy }\end{array}$ & $\begin{array}{l}\text { Hero: industry, } \\
\text { investors } \\
\text { Villain: EU, } \\
\text { environmental NGOs } \\
\text { Victim: forest } \\
\text { owners, Finland }\end{array}$ & $\begin{array}{l}\text { Using the constantly renewing } \\
\text { natural resources Finland has } \\
\text { brings prosperity while } \\
\text { addressing global } \\
\text { policy targets. }\end{array}$ & $\begin{array}{l}\text { Natural resources } \\
\text { should be used to } \\
\text { replace materials and } \\
\text { energy to generate } \\
\text { growth, employment, } \\
\text { and welfare }\end{array}$ \\
\hline $\begin{array}{c}3 \\
\text { Agroecological } \\
\text { bioeconomy }\end{array}$ & $\begin{array}{l}\text { Bioeconomy is about } \\
\text { understanding the } \\
\text { ecological and social } \\
\text { limits to growth }\end{array}$ & $\begin{array}{l}\text { Hero: forest owners, } \\
\text { farmers } \\
\text { Villain: industry, } \\
\text { policymakers } \\
\text { Victim: } \\
\text { future generations }\end{array}$ & $\begin{array}{l}\text { Bioeconomy helps us to } \\
\text { understand the limits to } \\
\text { growth and creates more } \\
\text { commitment to sustainable } \\
\text { natural processes and } \\
\text { bio-based solutions } \\
\text { and materials. }\end{array}$ & $\begin{array}{l}\text { The ecological and } \\
\text { social sustainability of } \\
\text { resource use should be } \\
\text { the guiding principle } \\
\text { for bioeconomy }\end{array}$ \\
\hline $\begin{array}{c}4 \\
\text { Bioeconomy as } \\
\text { skillfulness }\end{array}$ & $\begin{array}{l}\text { Bioeconomy is about } \\
\text { skills and learning } \\
\text { applied in local } \\
\text { practices } \\
\text { and policymaking }\end{array}$ & $\begin{array}{l}\text { Hero: local } \\
\text { professional } \\
\text { practitioners } \\
\text { Villain: ignorant } \\
\text { policymakers } \\
\text { Victim: future growth, } \\
\text { rural areas }\end{array}$ & $\begin{array}{l}\text { To use bio-based technologies } \\
\text { and resources successfully, } \\
\text { special skills, knowledge, } \\
\text { and competence are needed. } \\
\text { These are possessed by actors } \\
\text { with practical experience } \\
\text { and education. }\end{array}$ & $\begin{array}{l}\text { National funding for } \\
\text { education concerning } \\
\text { bio-based materials } \\
\text { and knowledge in local } \\
\text { contexts should be } \\
\text { guaranteed to make } \\
\text { bioeconomy work }\end{array}$ \\
\hline $\begin{array}{c}5 \\
\text { Climate } \\
\text { change-centered } \\
\text { bioeconomy }\end{array}$ & $\begin{array}{l}\text { Bioeconomy is about } \\
\text { answering the } \\
\text { challenges of climate } \\
\text { change while } \\
\text { maintaining growth }\end{array}$ & $\begin{array}{l}\text { Hero: higher-level } \\
\text { experts, policymakers } \\
\text { Villain: forest industry } \\
\text { Victim: climate, growth }\end{array}$ & $\begin{array}{l}\text { By carefully estimating the } \\
\text { balance between natural } \\
\text { resources, especially forests as } \\
\text { a carbon sink and source of } \\
\text { renewable materials and } \\
\text { energy, creates a win-win } \\
\text { situation for climate benefits } \\
\text { and future growth. }\end{array}$ & $\begin{array}{l}\text { Scientists should } \\
\text { determine how the } \\
\text { bio-based resources } \\
\text { and technologies } \\
\text { should best be used } \\
\text { to avoid } \\
\text { interest-based policies }\end{array}$ \\
\hline
\end{tabular}




\subsection{Biotechnology-Centered Bioeconomy}

In this narrative, the future is built on the development of new technologies and innovations that make use of natural resources or, better, use natural processes. In this narrative, bioeconomy is strongly connected to cleantech and digitalization, where the aim is to make Finland the frontrunner in the exportation of knowledge and technologies. The heroes are scientists and innovators who work towards novel solutions and the development of bio-based materials to replace fossil-based materials. This is not possible without support from the government, and the recent cuts in research and innovation funding are seen as a threat to this. Bio-based technology is urgently needed to solve several global problems, including the overuse of endangered resources as well as finding new ways to replace chemicals.

\subsection{Resource-Centered Bioeconomy}

This narrative makes natural resources the key to bioeconomy. These resources can be used to substitute current fossil-based products, including energy. This also addresses climate goals. The current large investment plans for forest-based bioproduct facilities are seen as a strong sign for this model of bioeconomy. Finland has vast forest resources that have the potential to make Finland the leader in bioeconomy and open a growth path. It is thus a national project that could create prosperity and employment for the whole country, including rural areas in decline. Thus, every effort should be made so that the EU bureaucrats and nations without knowledge of Finnish conditions or the multinational environmental organizations do not jeopardize this. The enemy can also be national if the Finnish environmental organizations or actors such as labor unions slow this process. The role of functioning logistics and infrastructure has been repeatedly brought to the fore, as timber must be moved from forests to the industrial facilities. If the resources cannot be used sufficiently regarding the national economy and economies of private forest owners, the climate will also suffer. Bioeconomy, as a resource, is also about securing national self-sufficiency. Besides forests, the use of fish stocks and other blue bioeconomy is discussed in terms of this narrative.

\subsection{Agroecological Bioeconomy}

Agroecological bioeconomy sees bioeconomy as a holistic model for sustainable production and consumption. It essential is to understand the limits to, for example, harvesting to avoid the possibilities of future generations using these resources being diminished. In this narrative, food production is more apparent than, for example, in the resource-centered narrative. Farmers especially were represented as possessing knowledge that makes the use of resources sustainable. The industrial actors with their quest to overexploit these resources are seen as the villains. This narrative has often characteristics of a counter narrative to the dominant resource narrative. It questions the plans to use natural resources as being overambitious and neglecting the need to also restrain the consumption of energy, instead of just replacing energy sources with natural resources. The plans for new, large-scale industrial facilities using wood are represented as the sole interest of certain political groups and the forest industry.

\subsection{Bioeconomy as Skillfulness}

The narrative of skillfulness emphasizes the role of skills and knowledge in bioeconomy. It is about knowing how the various practices around bioeconomy work. It resonates with some elements of the biotechnology and resource-centered narratives, in, e.g., seeing bioeconomy as the comprehensive ability to master the value chains and flows. It is not only of practical professionals, but also about skillful policymakers. Several articles talk, for example, about certain politicians who possess bioeconomy knowledge. The Center Party especially possesses this bioeconomy skillfulness. It is not only knowledge that can be thought only, but must be integrated with practices, be they policy practices or hands-on practices in the field and industrial facilities. Thus, it differs from knowledge 
in the scientific biotechnology narrative. The skillfulness narrative is, in essence, local, thus making the local communities crucial actors and, also, possible victims if this skillfulness is lacking. Practical education is the key and the cuts in vocational and lower polytechnic education in the name of efficiency was a disservice to bioeconomy. This skillfulness is also a key resource in the efforts to make bioeconomy the spearhead of the Finnish export industry.

\subsection{Climate Change-Centered Bioeconomy}

The climate change-centered narrative is one where, similar to the resource narrative, natural resources play a major role. The argumentation revolves around the issue of how to balance between forests being carbon sinks and a source to replace fossil-based products. The key issue is that the time scope and the heroes in this narrative are scientific experts and policymakers who understand the urgency and possess a holistic understanding of the global and interlinked problem of climate change. The villains are the forest industry and some politicians who use bioeconomy as an excuse to justify increasing felling in the name of false altruistic motives. Neglecting the science-based role of natural resources as carbon sinks also endangers future growth. The villains argue that maximizing resource use also benefits the climate, but the global policy environment does not support this claim. This is not so much a counter narrative to the resource-centered narrative, but rather, a realignment of the use of natural resources as a tool to tackle climate change.

\subsection{Narratives in the Newspapers}

Despite the difference in the number of bioeconomy articles between 2010-2011 (106) and 2015-2016 (1158), some comparison can be made, especially between the most recurrent narratives (Figure 2). The earlier media coverage represented bioeconomy as a biotechnology more often than the later coverage, although the resource narrative also dominated the earlier coverage. However, in the earlier coverage, bioenergy was represented as being separate from bioeconomy, whereas in the later coverage, bioenergy was explicitly part of bioeconomy and, for the most part, was narrated in the resource narrative, but also in the climate change narrative.

The formation of the Center Party-led government happened during spring 2015. The large share of articles with no bioeconomy narrative in the latter data were articles with merely one word mentioning the government bioeconomy strategy along with other spearhead projects or similar discussions. In the 2010-2011 data, similar current "neutral" policy-related articles discussed the idea of changing the Ministry of Agriculture and Forestry into a Ministry of Bioeconomy. In the former coverage, the allocation of articles was somewhat more difficult, as despite referring to bioeconomy, several articles carried no indication of what this would mean, other than a catchy, but abstract, promise.

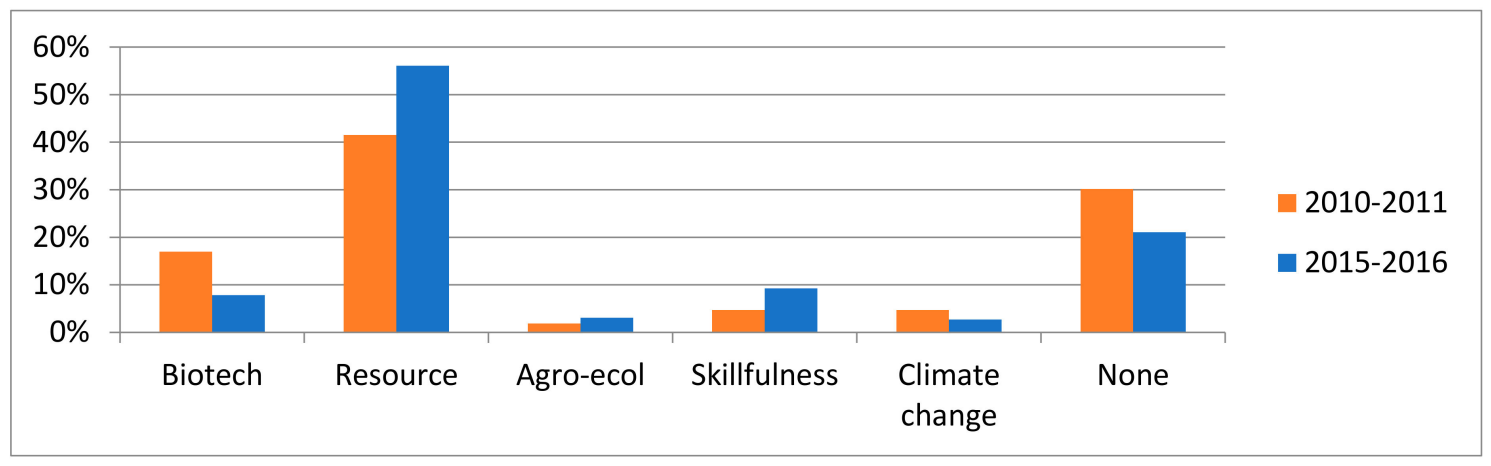

Figure 2. Share of different narratives in 2010-2011 and 2015-2016.

Figures 3 and 4 present how the different narratives were represented in the different newspapers. A comparison of the 2015-2016 coverage (Figure 4) between the newspapers shows that bioeconomy as 
biotechnology was most represented in Kauppalehti. Kauppalehti also had the strongest representation on the climate change narrative and was high on the resource-centered and agroecological narratives. The resource-centered narrative, which dominated all newspapers, was especially strong in Maaseudun Tulevaisuus, a paper that was also high in the skillfulness narrative. In Keskisuomalainen, the resource narrative was also very strong, but the skillfulness narrative was particularly supported in this newspaper, even more so than the biotechnology narrative. Helsingin Sanomat followed similar patterns to the other media, but the three narratives of lesser representation-agro-ecology, skillfulness, and climate change-were more evenly represented. Figures 3 and 4 include only the articles representing one of the narratives.

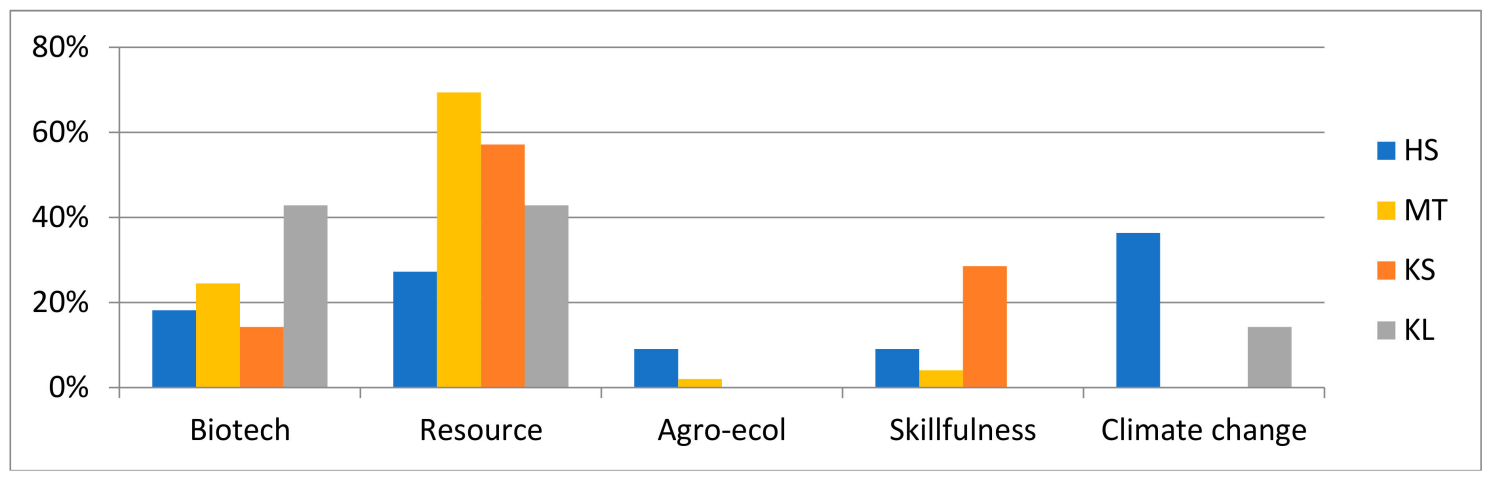

Figure 3. The division of the narratives across the newspapers in 2010-2011. HS = Helsingin Sanomat, MT = Maaseudun Tulevaisuus, KS = Keskisuomalainen, KL = Kauppalehti.

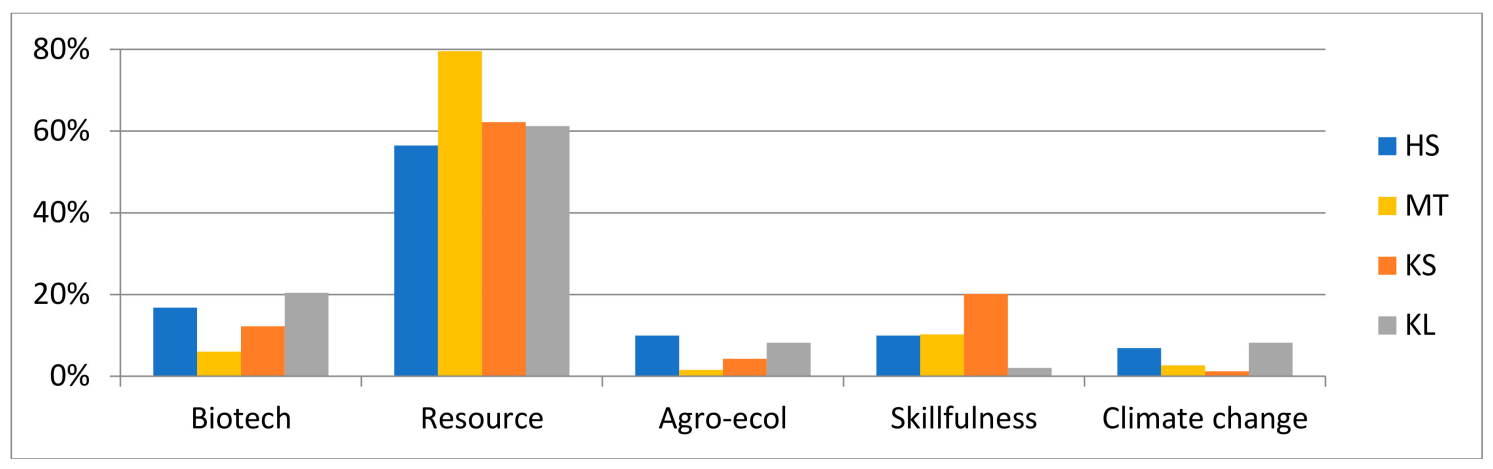

Figure 4. The division of the narratives across the newspapers in 2015-2016. HS = Helsingin Sanomat, MT = Maaseudun Tulevaisuus, KS = Keskisuomalainen, KL = Kauppalehti.

\section{Discussion}

\subsection{Actors and Non-Actors of Bioeconomy}

A comparison of the two data sets confirmed the observation that discussion on bioeconomy has risen significantly in the public realm in Finland, reflecting the rise of the agenda in EU research and innovation activities. Similar developments are also happening in other Nordic countries. However, the focus of empirical analysis has been mainly on policy documents and related processes and the visions and narratives therein $[3,4,12,14]$.

In the beginning of this paper, I proposed questions regarding the kinds of bioeconomy narratives promoted by the media and the actors in these narratives. The previously recognized three narratives, biotechnology, bioresources and agroecological bioeconomy $[2,3,10]$, were very much present in the media articles analyzed here. In addition to these three, two other narratives were recognized in the media: bioeconomy as skillfulness and climate change-centered bioeconomy. All five create a different understanding of bioeconomy with varying settings, policy solutions, and preferable futures. 
The most apparent finding is how the narrative of resource-based bioeconomy dominates the media discussions. It does it in different time scopes, but also cross-cuts different media. One explanation for this dominance is the formation of the government in 2015 which strongly emphasizes bioeconomy and clean solutions based on existing resources and industries and has a vision of bioeconomy as the future of Finland. However, this tendency is not only characteristic of the 2015 government. Bosman and Rotmans [38] noted that Finnish bioeconomy policies tend to support incremental innovation and existing industries, and Hausknost et al. [10] stated that the national bioeconomy policies in general seem to advocate a resource-based understanding of bioeconomy. Another interlinked explanation is the ongoing planning and construction of large-scale biorefineries that use wood; this was also supported by the word frequency analysis. The path dependencies and inertia stemming from forest-based industries certainly seem to play a role in the understanding of bioeconomy [3].

The four other narratives played smaller roles. Still, the small share of the biotechnology narrative over the resource narrative was slightly surprising. However, it could be that some biotechnology issues are discussed within the resource-centered narrative. The notion that that the biotechnology narrative is connected to the green growth paradigm and the bioresources within would support this interpretation [10].

The heavy use of forest and other natural resources as the basis of bioeconomy was criticized within the agroecological narrative, which claimed that bioeconomy does not question the overuse of natural resources but is merely a smokescreen for continuing and further escalating the unsustainable use of, especially, forests. This narrative is also one in which the vocal actors are farmers, citizens, or activists. It is thus less of an expert, policy, or industry-led narrative compared to the others.

The skillfulness narrative is an interesting case in point, as it includes the voices of local and regional policy and industry actors-something the other narratives seem to lack. It is indeed the regional level that plays a crucial role in the practical interlinkages between supranational policies, national strategies, and industries of different scales of bioeconomy [12]. The rise of education in the word frequency analysis further supports the interpretation that bioeconomy has, to some extent, moved from meta and top-level policy discussions into more practical implementation and practices.

The resource-centered narrative meets criticism also within the climate change-centered narrative, where using natural resources for products of low added value, such as pulp or energy, is argued to endanger how natural resources could contribute to mitigating climate change. Preserving or promoting ageing forests or products with longer life cycles, such as wood construction, would serve this purpose. Contrary to the agroecological narrative, the climate narrative is very much expert and scientist led.

When scrutinizing how the narratives appear in the different newspapers, it seems that the narratives questioning the dominant resource-centered narrative are stronger in Helsingin Sanomat and Kauppalehti than in the others. This is possibly due to how the two other papers, Maaseudun Tulevaisuus and Keskisuomalainen, represent the stances of rural actors who are more directly financially bound to the use of natural resources. In this, the local economy and the economic interests of local actors seem to overtake the other aspects of sustainability. The larger share of the skillfulness narrative in the regional Keskisuomalainen also reflects the connectedness of bioeconomy to local practices.

\subsection{Competing Futures for Bioeconomy}

As Hausknost et al. [10] points out, the biotechnology vision is often built on technological criteria, thus overlooking the power positions of the actors and political tensions. In addition, the national bioeconomy policies and visions tend to be built on the economic promises made in bioeconomy [4]. The active heroes in the media narratives were shown to be experts, policymakers, and the industry. Often the narratives were also the ones advocated by the heroes themselves, for example, forest professionals who promote the resource narrative simultaneously argue that it is these professionals 
who can make bioeconomy fulfill its promises. This tendency of the narrators to also be the heroes is typical of policy narratives [38].

One of the benefits of the NPF is the rigorousness of the analysis, which makes it possible to recognize what is lacking in the narratives. Perhaps except for the agroecological narrative, citizens and other actors who are not directly part of the domains of techno-science or policy were strikingly absent from the media discussions [39].

Even though there have been initiatives for participation in the preparation of, e.g., national bioeconomy strategies, they seem to have concentrated on informing, rather than seriously co-producing, contesting, and debating the principles and underlying assumptions with the citizens [16]. For the promises of bioeconomy to be realized, bioeconomy should be publicly accepted. This is particularly the case for the vast number of private forest owners whose implicit role seems to be that of a provider of bulk material.

This brings us to the third question of this paper: what kinds of futures do the narratives create and for whom? The conceptual matrix by Hausknost et al. [10] provides some possibilities for answering this question (Figure 5). When assessing how the narratives in the newspapers reflect the political-economic and technological dimensions, we found that the three previously recognized narratives held. However, in the media narratives, the resource-centered bioeconomy approach, which emphasizes growth and future competitiveness, was positioned even further right on the $x$-axis than indicated previously. Even though the argument goes that resources can be used sustainably, the underlying logic is that the use is done to accelerate growth. In comparison, the biotechnology narrative also supports the growth paradigm but is not driven by it in such magnitude, but rather, aims rather to transform existing processes or enhance technological innovation.

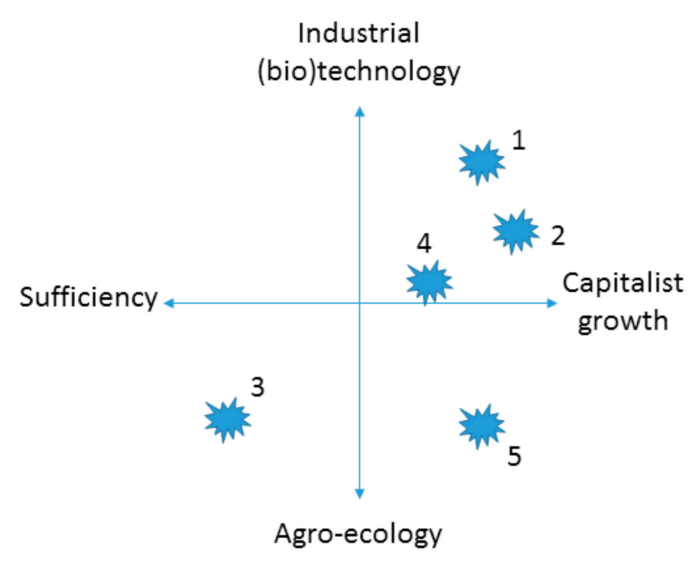

$\begin{array}{ll}1 & \text { Biotechnology-centered bioeconomy } \\ 2 & \text { Resource-centered bioeconomy } \\ 3 & \text { Agroecological bioeconomy } \\ 4 & \text { Bioeconomy as skillfulness } \\ 5 & \text { Climate change-centered bioeconomy }\end{array}$

Figure 5. The narratives in the techno-political option-space (adapted from Hausknost et al. [10]).

Whereas the resource-centered narrative leans towards the capitalist growth paradigm, the agro-ecology narrative appeared to be more critical of the growth paradigm compared to what was suggested by Hausknost et al. [10]. It thus seems that in the media, bioeconomy is discussed in more polarized terms that underline quite explicitly the fundamental logic of the differing ways of understanding bioeconomy than that of policy documents or even stakeholder statements.

Regarding the two new narratives, the skillfulness narrative with its emphasis on regional practices and knowledge is a balance between biotechnology and agro-ecology in the techno-political 
dimension, and in the political-economic dimension, it leans towards growth rather than sufficiency. However, the emphasis on the sustainability of rural livelihoods also supports the sufficiency aspect.

The climate change narrative tends to support the agroecological approach by stressing a holistic understanding of the processes of bioeconomy. In the political-economic dimension, it does not question the growth paradigm as such, but rather, argues that the possibility for future growth is only possible if the effects of escalating climate change do not ruin future possibilities.

The power of narratives lies in their power to affect policy processes and public opinion [30]. The media offers a platform for these narratives, but it should also be noted that the media advocates competing standpoints [40]. To analyze this, the NPF proved to be a well usable method that can also be used for longitudinal purposes as narratives are not stable but change over time. Sometimes these changes can happen over a relatively short period. An example of this is how the previously independent issues regarding bioenergy were almost completely included in the resource-based bioeconomy narrative in the later data. This is also an example of the flexibility of the concept $[3,19]$.

This flexibility can be harnessed to support varying interests. Bioeconomy can even be characterized as a master narrative that is ambiguous enough for the different actors to convincingly project their hopes and aspirations $[9,11]$. At worst, it can mean merely legitimizing unsustainable business by providing a societally accepted rhetorical device [22].

The threat is that if individual sectors manage to harness bioeconomy for their own narrow interests, the transition to truly more sustainable bioeconomy remains a mere promise. Hansen and Bjørkhaug [4] claimed that to avoid this development, radical realignment and integration along the related sectors is needed. The outlook is especially ominous if bioeconomy fails to incorporate and gain the legitimization of the citizens to support its visions. Narratives play a central role in this, but if the different standpoints are not taken more seriously and only the most powerful sectoral interests are promoted, there might be backlash that renders the visions meaningless.

\section{Conclusions}

Narratives can be regarded as assemblages of mutually constituted understandings of policy issues. The media is one key public arena where these policy narratives compete. The ways that issues such as bioeconomy are narrated can lead to support or questioning of the legitimacy of the related policies and can also affect the related practices. The use of narratives also raises power-related questions about the ways and by whom bioeconomy is narrated. The narratives do not appear neutrally from thin air but are constructed by actors who have varying visions on how to best make the transition to a sustainable bioeconomy happen as well as which societal actors this transition includes.

This inclusion or exclusion of actors has very practical potential consequences. If the forest owners, for example, conceive their role in bioeconomy to merely be providers of bulk as efficiently as possible, the increasing demand for timber might be compromised. Similarly, the narratives can also affect local policymaking and, for example, the decisions of companies in their investment decisions. For this reason, it makes a difference whether bioeconomy is discussed in terms of using and requiring industrial-scale high-tech solutions and processes or whether bioeconomy is based on agroecological processes that are usable in local practices.

The analysis of the bioeconomy narratives in the media showed how the resource-based continuum of the forest industry has a strong foothold in how bioeconomy is currently understood. There is obviously nothing wrong with this, as it provides matured knowledge and technologies on which to build on. However, if bioeconomy leads to mere incremental streamlining of current practices in the name of a catchy concept instead of radical re-thinking and alignment with the aspirations towards a circular economy, the transition to a more sustainable society with the help of bioeconomy will be lacking. The stronghold of resource-based bioeconomy can also risk the success of national policies if the narratives keep supporting a view of bioeconomy that fails to consider the sometimes rapidly changing international policy climate. Examples of this can be seen, for example, in the discussions on how the role of forests as carbon sinks is gaining momentum at the expense of using 
bio-based materials to replace fossil fuels. On top of this, if the dominant understanding of bioeconomy leaves no role for the civil society, the sustainability of bioeconomy will be questioned.

Funding: This research was funded by the Kone Foundation.

Acknowledgments: The author is grateful for help provided by Jari Kolehmainen in collecting the media articles.

Conflicts of Interest: The author declares no conflict of interest.

\section{Appendix}

The analyzed articles and classifications.

\section{References}

1. Mickwitz, P.; Seppälä, J.; Kauppi, L.; Hildén, M. Towards a Carbon Neutral Circular Economy. Research Enhancing the Transition; SYKE Policy Briefs; Finnish Environment Institute: Helsinki, Finland, 2014.

2. Bugge, M.M.; Hansen, T.; Klitkou, A. What is the bioeconomy? A review of the literature. Sustainability 2016, 8, 691. [CrossRef]

3. Scordato, L.; Bugge, M.M.; Fevolden, A.M. Directionality across diversity: Governing contending policy rationales in the transition towards the bioeconomy. Sustainability 2017, 9, 206. [CrossRef]

4. Hansen, L.; Bjørkhaug, H. Visions and Expectations for the Norwegian Bioeconomy. Sustainability 2017, 9, 341. [CrossRef]

5. Meyer, R. Bioeconomy Strategies: Contexts, Visions, Guiding Implementation Principles and Resulting Debates. Sustainability 2017, 9, 1031. [CrossRef]

6. Bosman, R.; Rotmans, J. Transition governance towards a Bioeconomy: A Comparison of Finland and the Netherlands. Sustainability 2016, 8, 1017. [CrossRef]

7. Ministry of Employment and the Economy. Sustainable Growth from Bioeconomy. The Finnish Bioeconomy Strategy; Ministry of Employment and the Economy: Helsinki, Finland, 2014.

8. Siiskonen, $\mathrm{H}$. The conflict between traditional and scientific forest management in 20th century Finland. For. Ecol. Manag. 2007, 249, 125-133. [CrossRef]

9. Birch, K.; Levidow, L.; Papaioannou, T. Sustainable capital? The neoliberalization of nature and knowledge in the European "knowledge-based bio-economy". Sustainability 2010, 2, 2898-2918. [CrossRef]

10. Hausknost, D.; Schriefl, E.; Lauk, C.; Kalt, G. A transition to which bioeconomy? An exploration of diverging techno-political choices. Sustainability 2017, 9, 669. [CrossRef]

11. Levidow, L.; Birch, K.; Papaioannou, T. Divergent paradigms of European agro-food innovation: The knowledge-based bio-economy (KBBE) as an R\&D agenda. Sci. Technol. Hum. Values 2013, 38, 94-125.

12. De Besi, M.; McCormick, K. Towards a bioeconomy in Europe: National, regional and industrial strategies. Sustainability 2015, 7, 10461-10478. [CrossRef]

13. Pfau, S.F.; Hagens, J.E.; Dankbaar, B.; Smits, A.J. Visions of sustainability in bioeconomy research. Sustainability 2014, 6, 1222-1249. [CrossRef]

14. Bauer, F. Narratives of biorefinery innovation for the bioeconomy-Conflict, consensus, or confusion? Environm. Innov. Soc. Transit. 2018. [CrossRef]

15. McCormick, K.; Kautto, N. The bioeconomy in Europe: An overview. Sustainability 2013, 5, 2589-2608. [CrossRef]

16. Davies, S.; Griestop, L.; Vironen, H.; Bachtler, J.; Dozhdeva, V.; Michie, R. Case Studies of National Bioeconomy Strategies in Finland and Germany. Available online: Cordis.europa.eu/result/rcn/198231_en. html (accessed on 17 August 2018).

17. Kröger, M.; Raitio, K. Finnish forest policy in the era of bioeconomy: A pathway to sustainability? For. Policy Econ. 2017, 77, 6-15. [CrossRef]

18. Meadowcroft, J. Planning for substainable development: Insights from the literatures of political science. Eur. J. Polit. Res. 1997, 31, 427-454. [CrossRef]

19. Leigh Star, S. This is not a boundary object: Reflections on the origin of a concept. Sci. Technol. Hum. Values 2010, 35, 601-617. [CrossRef] 
20. Shanahan, E.A.; McBeth, M.K.; Hathaway, P.L.; Arnell, R.J. Conduit or contributor? The role of media in policy change theory. Policy Sci. 2008, 41, 115-138. [CrossRef]

21. Peltomaa, J.; Hildén, M.; Huttunen, S. Translating institutional change-Finnish forest journals as forest policy actors. For. Policy Econ. 2016, 70, 172-180. [CrossRef]

22. Ramcilovic-Suominen, S.; Pülzl, H. Sustainable development-A 'selling point'of the emerging EU bioeconomy policy framework? J. Clean. Prod. 2016, 172, 4170-4180. [CrossRef]

23. Staffas, L.; Gustavsson, M.; McCormick, K. Strategies and Policies for the Bioeconomy and Bio-Based Economy: An Analysis of Official National Approaches. Sustainability 2013, 5, 2751-2769. [CrossRef]

24. Organisation for Economic Cooperation and Development (OECD). The Bioeconomy to 2030: Designing a Policy Agenda; OECD International Futures Project; OECD Publishing: Paris, France, 2009.

25. European Commission (EC). EUROPE 2020: A Strategy for Smart, Sustainable and Inclusive Growth; COM (2010) 2020; Office for Official Publications of the European Communities: Brussels, Belgium, 2010.

26. European Commission (EC). A Resource-Efficient Europe-Flagship Initiative under the Europe 2020 Strategy; COM (2011) 21; Office for Official Publications of the European Communities: Brussels, Belgium, 2011.

27. European Commission (EC). Innovating for Sustainable Growth: A Bioeconomy for Europe; COM (2012) 60; Office for Official Publications of the European Communities: Brussels, Belgium, 2012.

28. Jones, M.D.; McBeth, M.K. A narrative policy framework: Clear enough to be wrong? Policy Stud. J. 2010, 38, 329-353. [CrossRef]

29. Jones, M.D.; McBeth, M.K.; Shanahan, E.A. Introducing the narrative policy framework. In The Science of Stories; Jones, M., Shanahan, E., McBeth, M., Eds.; Palgrave Macmillan: London, UK, 2014; pp. 1-25.

30. O’Bryan, T.; Dunlop, C.A.; Radaelli, C.M. Narrating the "Arab Spring": Where Expertise Meets Heuristics in Legislative Hearings. In The Science of Stories; Jones, M., Shanahan, E., McBeth, M., Eds.; Palgrave Macmillan: London, UK, 2014; pp. 107-129.

31. Jones, M.D.; Radaelli, C.M. The narrative policy framework: Child or Monster? Crit. Policy Stud. 2015, 9, 339-355. [CrossRef]

32. Sabatier, P.A.; Jenkins-Smith, H.C. The advocacy coalition framework: An assessment. In Theories of the Policy Process; Westview Press: Boulder, CO, USA, 1999; pp. 117-166.

33. Hsieh, H.F.; Shannon, S.E. Three approaches to qualitative content analysis. Qual. Health Res. 2005, 15, 1277-1288. [CrossRef] [PubMed]

34. Helsingin Sanomat. Available online: https://media.sanoma.fi/en/media-audiences/news-media/ helsingin-sanomat (accessed on 16 November 2018).

35. Maaseudun Tulevaisuus. Available online: mediamyynti.mt.fi/wp-content/uploads/2018/09/MT_Media_ Information_2018_13.9.2018.pdf/ (accessed on 16 November 2018).

36. Keskisuomalainen. Available online: mediamyynti.ksml.fi/tuotteet/?_ga=2.187266216.1837362632. 1495011400-1340605652.1495011018 (accessed on 16 November 2018).

37. Kauppalehti. Available online: www.almamedia.fi/en/advertisers/media-and-services/finance-and-b2bmedia/kauppalehti-fi (accessed on 16 November 2018).

38. Lybecker, D.L.; McBeth, M.K.; Husmann, M.A.; Pelikan, N. Do New Media Support New Policy Narratives? The Social Construction of the US-Mexico Border on YouTube. Policy Internet 2015, 7, 497-525. [CrossRef]

39. Peltomaa, J.; Kolehmainen, J. Ten years of bioeconomy in the Finnish media. Alue ja Ympäristö 2016, 46, 57-63.

40. Crow, D.A.; Lawlor, A. Media in the Policy Process: Using Framing and Narratives to Understand Policy Influences. Rev. Policy Res. 2016, 33, 472-491. [CrossRef]

(C) 2018 by the author. Licensee MDPI, Basel, Switzerland. This article is an open access article distributed under the terms and conditions of the Creative Commons Attribution (CC BY) license (http://creativecommons.org/licenses/by/4.0/). 